\title{
IN-SITU FILM-FORMING SOLUTION FOR TOPICAL APPLICATION OF TERBINAFINE HCL: BIOPHARMACEUTICAL EVALUATION AND IN VIVO ANTIFUNGAL PERFORMANCE USING ANIMAL MODEL
}

\author{
MOHD FAIZ MUSTAFFA*, KALAVATHY RAMASAMY, NAQIBAH JAAFAR, MIZATON HAZIZUL HASAN, NOR \\ AMLIZAN RAMLI, SURAYA SURATMAN, AISHAH ADAM
}

Faculty of Pharmacy, Universiti Teknologi MARA (UiTM), 42300 Bandar Puncak Alam, Selangor, Malaysia *Email: mohdfaiz@uitm.edu.my

Received: 30 Jun 2021, Revised and Accepted: 16 Aug 2021

\begin{abstract}
Objective: The main purpose of this study is to develop a film-forming solution with optimum physical-mechanical characteristics and excellent antifungal activity to enhance deposition and penetration into the stratum corneum (SC).

Methods: The film-forming solutions of terbinafine $\mathrm{HCl}$ were formulated using methacrylate copolymers, polyethylene glycol 400 , and ethanol as diluent. The selected formulations were subjected to test of physical-mechanical properties, drug release, drug permeation across the stratum corneum and drug deposition study. The best formulation was further evaluated for in vivo antifungal efficacy.

Results: The selected formulations exhibited superior pharmaceutical characteristics, including rapid drying, non-stickiness, and being transparency on the skin. Formulation A (FA) had significantly lower tensile strength $\left(4.78 \mathrm{~N} / \mathrm{m}^{2}, p<0.05\right)$ and higher percentage elongation at break (33.61\%, $\left.p<0.05\right)$, which reduced the firmness of the film, allowing it to be super-flexible in following the movement of the skin and preventing loss of film through abrasion. FA showed significantly $(p<0.05)$ rapid drug permeation $\left(1510.51 \mu \mathrm{g} / \mathrm{cm}^{2}\right)$ across the stratum corneum (SC) at $24 \mathrm{~h}$ when compared with the other formulations and the positive control proprietary drug (PD), Terbex® cream formulation $\left(475.8 \mu \mathrm{g} / \mathrm{cm}^{2}\right)$.
\end{abstract}

Conclusion: Having superior physical-mechanical and drug permeation characteristics, FA can be considered as an efficient, reproducible, and efficacious antifungal formulation for topical application.

Keywords: Terbinafine HCL, In situ film-forming solution, Topical application, Dermatophytes, Drug permeation, Stratum corneum, Antifungal

(C) 2021 The Authors. Published by Innovare Academic Sciences Pvt Ltd. This is an open access article under the CC BY license (https://creativecommons.org/licenses/by/4.0/)

DOI: https://dx.doi.org/10.22159/ijap.2021v13i6.42589. Journal homepage: https://innovareacademics.in/journals/index.php/ijap

\section{INTRODUCTION}

Dermatophytosis infects more than $20 \%$ of the world population [1] and is the most frequent source of infection, especially in tropical countries $[2,3]$. These infections are not life-threatening but are responsible for the largest global burden of years lived with disability (YLDs) which are in fact, higher (36.4 million) than diabetes mellitus (29.5 million) and migraine (28.9 million) [4]. Dermatophytosis can cause morbidity, especially amongst immunocompromised patients and those suffering from chronic diseases and amongst the elderly [5].

Topical drugs continue to be the mainstay in treating cutaneous infections [6]. Local effects attained in a topical drug delivery system is superior over oral treatment. The success of topical antimicrobial therapy, however, depends on the ability of a drug to enter the SC and follicular keratin and it must be retained at the infection site for an effective period of time [7]. The skin, in particular the SC, poses a formidable barrier to drug permeation $[6,8]$. Recent studies reported that antifungals generally exhibit excellent activity in vitro, but have a low capacity for penetrating the SC in skin models [8]. Compromised ability to retain a drug at the site of infection may lead to reduced efficacy and development of drug resistance $[5,9]$. This is evident from incidences of resistance to common drugs for treating dermatophytoses such as terbinafine, fluconazole, and griseofulvin [10-12]. Resistance arises as a consequence of non-adherence to prescribed treatment regimens, repetitive use of antifungal drugs more than once in a patient's life, the incidence of reabsorption or washout of drug from the skin and failure of the drug to reach the SC $[10,11]$. Higher treatment failures $(40-60 \%)$ and relapse incidences $(22.2 \%$ after $3 \mathrm{y})$ give rise to questions about the efficacy of current anti-microbial preparations with consequent implications on morbidity and mortality [13]. Current topical anti-infective preparations are available in the form of ointments, creams, gels, lotions, and shampoo. These preparations have certain limitations like poor persistent contact with site of treatment, poor drug permeability, and compromised patient compliance due to them being messy, sticky, possessing an unattractive appearance, and interference with daily activities [14]

The use of film-forming dermal and/or transdermal delivery of drugs [15] has therefore been explored. Film-forming solutions have a unique attribute, which is being a non-solid dosage form of solution during the storage period that can be converted into the form of a film in-situ upon application. They induce the supersaturation of the drug upon solvent evaporation and the formed film is occlusive and increases skin hydration which leads to a high flux of drug across the SC. Besides, the film is not removed from the site by clothing, gauze, etc. A film-forming system hybridised with econazole loaded nanostructured lipid carrier showed markedly higher drug permeation (1.5 fold) across SC and deposition ( 3 fold) in the skin layer compared to a conventional marketed product (6).

These delivery systems are, however, not without disadvantages. A voriconazole-loaded film-forming transdermal spray required a long time for film formation (up to $4 \mathrm{~min}$ ) and to completely treat the infection site (up to $14 \mathrm{~d}$ ) on male Wrister rats [16]. Gel formulation of rotigotine with hydroxypropyl cellulose and carbomer 934 also required about 3-5 min for film formation and had only $22.6 \%$ absolute bioavailability [17]. A tolterodine film-forming hydrogel precipitated within $3 \mathrm{~min}$ to form whitish films [18]. Yang et al. reported that terbinafine $\mathrm{HCl}$ and urea-loaded film-forming system for onychomycosis took 2 to $3 \mathrm{~min}$ to form a clear flexible film but had poor correlation coefficient of drug release profile [15]. The commercial preparation Lamisil ONCE® film-forming solution that consists of terbinafine $\mathrm{HCl}(1 \%(\mathrm{w} / \mathrm{w})$, forms a rough film with particles upon application that causes poor appearance and patient compliance [15]. Lamisil ONCE® shows poor drug permeation and retention due to the crystallisation of terbinafine $\mathrm{HCl}$ resulting in failure of drug penetration across the SC which leads to treatment failure and high relapse incidences [19]. All these findings emphasise the need to take into account the physical and chemical characteristics of topical products when designing film-forming 
solutions. Besides satisfying consumer needs, formulation concerns i.e., drying time, formation of a transparent and flexible film, ease of application, high drug permeation across the SC, and effectiveness of formulation, must be considered. This study, therefore, is aimed at developing a topical dosage form using a film-forming solution to overcome the drawbacks of the existing conventional topical formulations. We hypothesise that the film-forming terbinafine $\mathrm{HCl}$ formulation in the present study will form a thin, transparent, nonsticky and flexible film which dries in less than $1 \mathrm{~min}$ and has good drug permeation across the SC to improve dermatologic outcomes for the treatment of cutaneous fungal infections.

\section{MATERIALS AND METHODS}

\section{Materials}

The film-forming solutions were prepared using methacrylate copolymer (Evonik Röhm GmbH, Darmstadt, Germany) of Eudragit L100, S100, and L100-55; hydroxypropyl methylcellulose (HPMC, Merck Milipore, USA); polyethylene glycol 400 (PEG400, Merck Milipore, USA), ethanol (Thermo Fischer Scientific, USA) and terbinafine HCl (USP Convention, USA). Deionised water was obtained using a Milli-Q system from Millipore. The proprietary drug Terbex $®$ ( $1 \%$ terbinafine $\mathrm{HCl}$ cream, Bemxico Pharma, Bangladesh) was used for positive control. Acetonitrile and tetrahydrofuran HPLC grade (Thermo Fischer Scientific, USA) were used for HPLC assays. Trichophyton rubrum (ATCC-10218), sabouraud dextrose agar (SDA, Life Technologies, USA), RPMI 1640 with glutamine (Life Technologies, USA), and cocktails of ketamine, xylazine, tiletamine and zolazepam (Virbac, France) were used for an in vivo animal study.

\section{Formulation}

The film-forming solution was formulated by dissolving $10-20 \%$ $(\mathrm{w} / \mathrm{v})$ methacrylate copolymers alone or in combination with hydroxypropyl methylcellulose (HPMC) in $70 \%(\mathrm{v} / \mathrm{v})$ ethanol that was left to stir overnight. To this solution, 3-5\% (v/v) PEG400 and 1\% $(\mathrm{w} / \mathrm{v})$ terbinafine $\mathrm{HCl}$ were finally added. The volume of ethanol was made up to $100 \%$ and left to stir overnight. The prepared formulations were screened and selected for desired quality attributes i.e., low viscosity, fast drying (less than $1 \mathrm{~min}$ ), forms a non-sticky, transparent, and detachable film as described by Zurdo Schroeder et al. but with slight modifications [20]. Five formulations which fulfilled all specified criteria were subjected to tests of physical and mechanical properties. The prepared formulations were stored in an amber bottle at room temperature until further use.

\section{Determination of physical-mechanical properties}

\section{a) Uniformity of thickness and weight of forming films}

Film thickness was measured at six different points by a digimatic thickness gauge (Mitutoyo, Japan) and each dried film was weighed individually. The mean values for thickness and weight of six films were recorded as specified in USP 34,<905>Uniformity of Dosage Unit [21]

\section{b) Measurement of $\mathbf{p H}$}

The $\mathrm{pH}$ of various formulations was determined using a digital $\mathrm{pH}$ meter [14]. The $\mathrm{pH}$ of each formulation was measured in triplicates and mean values were calculated.

\section{c) Water content}

The films were immersed in $5 \mathrm{ml}$ of PBS pH 5.5 for $24 \mathrm{~h}$ after which they were placed on filter papers to remove excess water. Swollen films were weighed and left to dry at room temperature until constant weight (Ws). The films were dried again in a vacuum oven (Labwit ZRD-5055, Malaysia) for $6 \mathrm{~h}$ at $60{ }^{\circ} \mathrm{C}$ to determine if the films were able to stand without changing its physical and chemical characteristics [14]. The dried films were weighed (Wd), and the percentage (\%) of water content was calculated as follows:

$$
\text { Water content }(\%)=\frac{(\mathrm{Ws}-\mathrm{Wd})}{\mathrm{Ws}} \times 100 \mathrm{Eq} \cdot(1)
$$

\section{d) Percentage of moisture uptake capacity}

The weighed film was kept in a desiccator at room temperature for $24 \mathrm{~h}$ and was exposed to $84 \%$ relative humidity until a constant weight was obtained. The percentage of moisture uptake was calculated as the difference between the final and initial weights with respect to initial weight [22].

\section{e) Water vapor permeability (WVP)}

A $10 \mathrm{ml}$ glass vial was filled with $10 \mathrm{ml}$ of phosphate buffer solution (PBS) $\mathrm{pH} 5.5$ at $32 \pm 2{ }^{\circ} \mathrm{C}$ and covered with the dried films and sealed tightly with aluminium foil which was kept in place by a silicone ring [14]. The vials $(n=6$ per formulation) were left on a heater $(32 \pm 0.5$ ${ }^{\circ} \mathrm{C}$ ) and the relative humidity (RH) was monitored. The samples were individually weighed at 0 and $24 \mathrm{~h}$. WVP was calculated from the weight loss of the vials $\mathrm{W}(\mathrm{g})$ in relation to time $\mathrm{t}(24 \mathrm{~h})$ and surface permeability area $\mathrm{A}\left(1.54 \mathrm{~cm}^{2}\right)$.

$$
\mathrm{WVP}\left(\mathrm{g} \mathrm{cm}^{-2} 24 \mathrm{~h}^{-1}\right)=\frac{\mathrm{W}}{\mathrm{A} * \mathrm{t}} \text { Eq. (2) }
$$

\section{f) Mechanical properties}

The dried films were subjected to a tensile tester (TA. XT plus Texture analyser, USA) with a mounting load of $30 \mathrm{~kg}$ according to $\mathrm{Ng}$ and Tan but with slight modifications [22]. Six samples $(2 \mathrm{~cm} \times 2$ $\mathrm{cm}$ ) of each formulation were placed between two vertical grips and tested with an extension speed of $5 \mathrm{~mm} / \mathrm{min}$ until the film ruptured. From the recorded load time profiles, tensile strength $(\sigma)$ and elongation at break were calculated as follows:

$$
\begin{gathered}
\sigma\left(\mathrm{N} \mathrm{m}^{-2}\right)=\frac{\text { Fmax }}{\mathrm{Ai}} \text { Eq. (3) } \\
\varepsilon(\%)=\frac{\mathrm{Lr}}{\mathrm{Lo}} \times 100 \text { Eq.(4) }
\end{gathered}
$$

Where Fmax is the maximum force and A $i$ is the initial crosssectional area of the sample, $L_{r}(\mathrm{~m})$ is the extension of the sample at the moment of rupture, and $L_{0}(\mathrm{~m})$ is the original sample length. An average of six readings was recorded.

\section{Quantification of terbinafine $\mathrm{HCl}$ using reverse phase-HPLC}

The HPLC assay was adopted from terbinafine $\mathrm{HCl}$ standard drug monograph, USP (2009) Terbinafine HCl was analysed using RPHPLC that consisted of a pump (Agilent 1200), UV detector and reversed-phase HPLC column (Agilent Zorbax SB-C18 HPLC (250 $\mathrm{mm} \times 4.6 \mathrm{~mm}, 5 \mu \mathrm{m})$. The mobile phase was acetonitrile: water: tetrahydrofuran $(70: 25: 5(\mathrm{v} / \mathrm{v}))$. The analysis time was about 35 min with a flow rate of $0.7 \mathrm{ml} / \mathrm{min}$. UV detection was performed at $254.16 \mathrm{~nm}$ at a retention time (Rt) of $13.5 \mathrm{~min}$, which resulted in a good resolution and separation efficiency. The method was found to be accurate and precise with 95.01 to $101.63 \%$ of recovery and 0.34 to $1.34 \%$ for R. SD, respectively. HPLC assay showed good linearity $\left(\mathrm{R}^{2}=0.9997\right)$ with limit of detection and limit of quantitation for terbinafine at $0.1 \mu \mathrm{g} / \mathrm{ml}$ and $0.5 \mu \mathrm{g} / \mathrm{ml}$, respectively.

\section{Drug content analysis}

Each prepared film-forming solution or Terbex®cream was weighed $(1 \mathrm{~g})$ and diluted with $100 \mathrm{ml}$ of pure ethanol in a $250 \mathrm{ml}$ volumetric flask. From this solution, $1 \mathrm{ml}$ was transferred to a $10 \mathrm{ml}$ volumetric flask and the volume topped up to $10 \mathrm{ml}$. Two $\mathrm{ml}$ of the solution was filtered through a $0.45 \mu \mathrm{m}$ nylon filter and subjected to RP-HPLC for quantitative assay. The experiment was performed in six replicates for each batch and the average value was calculated.

\section{In vitro drug release analysis}

Release of terbinafine $\mathrm{HCl}$ from in-situ film-forming solutions (FAFE) and Terbex $\AA$ cream was performed using a Franz-type diffusion cell with a nylon membrane $(0.45 \mu \mathrm{m})$ placed in between the donor and receptor compartments. Five ml PBS (pH 5.5) was employed as the receptor phase and the temperature was maintained at $32 \pm 0.5$ ${ }^{\circ} \mathrm{C}$ using a circulating water jacket and agitated by a magnetic stir bar. The receptor fluid was removed at 8 -time points; post $0.25 \mathrm{~h}$, $0.5 \mathrm{~h}, 1 \mathrm{~h}, 2 \mathrm{~h}, 4 \mathrm{~h}, 6 \mathrm{~h}, 12 \mathrm{~h}$, and $24 \mathrm{~h}$ and immediately replaced with an equal volume of fresh diluents. All samples were filtered through a $0.45 \mu \mathrm{m}$ nylon filter and analysed by HPLC. The assay was performed in triplicates and at three different sites of donor skin samples. The data were fitted to four kinetic models [23, 24] i.e. 
zero-order kinetic, first-order kinetic, Higuchi classical kinetic, and Korsmeyer-peppas kinetic to investigate the kinetic mechanisms of terbinafine HCL release from formulations.

\section{Animals}

The present study was approved by the Committee on Animal Research and Ethics (CARE) of UiTM (UiTM Care: No 196/2017). Male Sprague Dawley (SD) rats $(n=30)$ weighing $150-300$ g were obtained from LAFAM, Faculty of Pharmacy, UiTM. All the animals have housed in individually ventilated cages [IVC] (Modular Animal Caging Systems, Alternative Design, Manufacturing and Supply, Inc., Siloam Springs, Arkansas, USA) at 10\% negative pressure with respect to a room that had a natural light-dark cycle (12 h each). Corn cobs (Bed-0' Corbs 1/4) were used as bedding material and changed weekly or as and when required. All rats had access to food (Gold Coin Feed Mills, Penang, Malaysia) and water ad libitum.

\section{Drug permeation and drug retention analysis}

Permeation analysis was conducted by using the hairless abdominal skin (25 pieces) of SD rats [25]. The animals were sacrificed by overdose inhalation of diethyl ether. Hair on the dorsal side of the animal was removed with a $0.1 \mathrm{~mm}$ animal hair clipper, in the direction of tail to head. The dermis part of the skin was wiped 3 to 4 times with a wet cotton swab soaked in isopropanol to remove any adhering fat and the skin was then examined thoroughly for any surface skin abnormalities such as fissures or tiny hole. The skin was mounted on the receptor chamber of the Franz Diffusion Cell (PermeGear, USA). The surface area exposed to the test compound had a cross-sectional area of $3.14 \mathrm{~cm}^{2}$ (2 cm in diameter). PBS (pH 5.5, 5 $\mathrm{ml})$ was employed as the receptor phase and the temperature was maintained at $32 \pm 0.5^{\circ} \mathrm{C}$ using a circulating water jacket and agitated by a magnetic stir bar. The receptor fluid was removed at 6 -time points; post 1 h, 2 h, 4 h, 6 h, 12 h, and 24 h. Fluid removed from the receptor compartment was immediately replaced with an equal volume of fresh diluents. All samples were filtered through a $0.45 \mu \mathrm{m}$ nylon filter and analysed by HPLC. The assay was performed in triplicates and at three different sites on the skin samples.

At the end of the experiment, the skin was wiped twice with cotton gauze to remove the residual formulation. Tape disk was applied and removed with pincers, using gentle pressure with the blunt end after application to ensure good skin contact. The application of tape disk at the respective sites was repeated 13 times. To avoid potential contamination by drug residue, the first tape strip was discarded, and remaining tapes were extracted in groups of three by shaking overnight with $5.0 \mathrm{ml}$ of PBS. The mixture was filtered and quantified using RP-HPLC. The drug permeation and drug retention were determined using the Area under Curve (AUC) method and compared with calibration plots that were generated with pure compounds.

The drug permeation profile of terbinafine $\mathrm{HCl}$ in each tested formulation was determined over $24 \mathrm{~h}$ and plotted based upon the cumulative amount of drug permeated against time. The flux ( $\mu \mathrm{g} \mathrm{cm}$ ${ }^{2} \mathrm{~h}^{-1}$ ) of terbinafine $\mathrm{HCl}$ was calculated from the slope of the obtained plot. The steady state permeability coefficient $(K p)$ of the drug through the SC was deduced by using the Fick's law equation:

$$
\mathrm{Kp}=\frac{\mathrm{J}}{\mathrm{C}} \text { Eq. (5) }
$$

Where $\mathrm{J}$ is the flux and $\mathrm{C}$ is the concentration of terbinafine $\mathrm{HCl}$ in the formulations.

\section{Cutaneous infection and treatment}

Cutaneous infection studies were carried out according to Mori et al. with slight modifications [16]. Male SD Rats (150-300 g) were anesthetised intraperitoneally with a cocktail of ketamine 100 $\mathrm{mg} / \mathrm{ml}$, xylazine $20 \mathrm{mg} / \mathrm{ml}$, tiletamine $50 \mathrm{mg} / \mathrm{ml}$, and zolazepam 50 $\mathrm{mg} / \mathrm{ml}$ at a dose of $0.1 \mathrm{ml} / 100 \mathrm{~g}$. Electric clippers and depilatory cream were used to remove hairs from rat flanks. An area of skin (20 $\mathrm{mm}$ in diameter) on each flank was scarified with coarse sandpaper to irritate the SC of the rats. T. rubrum $\left(200 \mu \mathrm{l} ; 1 \times 10^{6}\right.$ conidia) were inoculated at the respective areas and covered by a sterile adhesive bandage with extra adherent tape. The bandage was held in place for $72 \mathrm{~h}$ before initiating treatment. On the third day, infected animals were randomly assigned into four groups comprising of six animals per group, including negative control (without any treatments), placebo (FA without drug), Terbex $囚$, and FA. Each treatment $(40 \mu \mathrm{l})$ was applied once daily for seven consecutive days. The efficacy of the treatments was examined using morphological and mycological evaluations.

\section{Morphological evaluation}

The mean areas of crust formation and skin lesions were examined visually daily. The area of crust formation, skin lesions, and papules formation (fig. 1) of each animal was measured using transparent graph paper. The mean area is the sum of the area of crust, skin lesion, and papules formed of all test animals in each group divided by the number of animals in that group.

\section{Mycological evaluation}

The work of Thapa et al. was adopted with a slight modification for mycological evaluation of cutaneous infections [19]. The animals were exposed to diethyl ether at the end of the experiment. The infected skins were excised and cut into 10 small blocks of $2 \mathrm{~mm} \times 2$ $\mathrm{mm}$ each and implanted on SDA plates containing $50 \mu \mathrm{g} / \mathrm{ml}$ of chloramphenicol and $50 \mu \mathrm{g} / \mathrm{ml}$ of gentamycin. The inoculated plates were incubated at $28{ }^{\circ} \mathrm{C}$ for $7 \mathrm{~d}$ and examined for evidence of visible growth. The fungal growth of any skin block was considered funguspositive skin. Intensity of infection was assessed with scores ranging from 0 to 10 , based on the number of culture-positive tissue blocks from the 10 tissue blocks/skin studied.

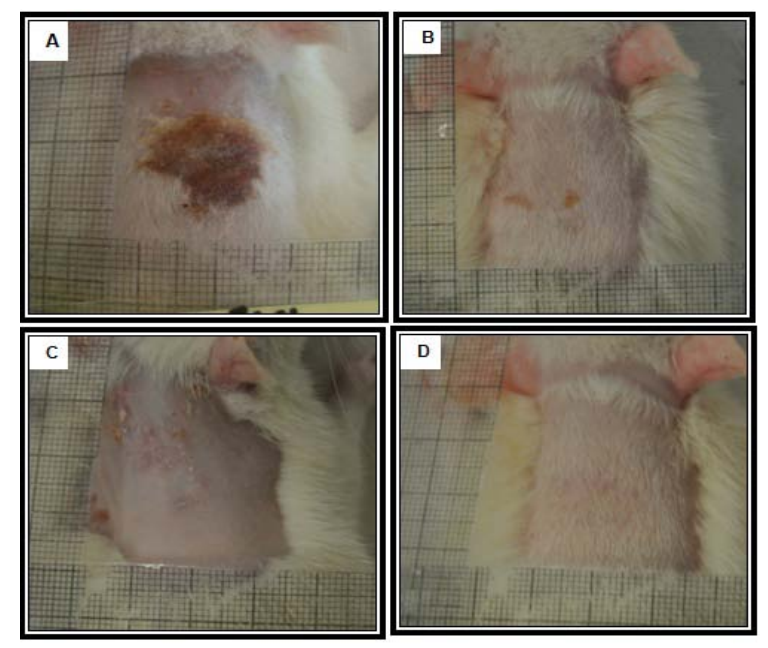

Fig. 1: Clinical scores. (A) Presence of crust, (B) Small erythematous (redness of skin) and lesion score normal, (C) Small erythematous and presence of small papules, and (D) Completely healed and growth of hair 


\section{Statistical analysis}

The results were presented as mean \pm standard deviation of the mean (SD). Analysis of variance (ANOVA) test with Duncan's post-hoc test were used to analyse and compare between the group data, with $p<0.05$ as the limit of significance.

\section{RESULTS AND DISCUSSION}

\section{Physical-mechanical properties}

The physical-mechanical properties of each experimental batch are crucial to ensure that the laboratory data can be translated or scaled up for bulk manufacturing. In the formulation process, ratios of excipients (polymer, plasticiser, and diluents) are crucial. Different ratios of plasticiser and polymer can alter the physical and mechanical properties of prepared formulations.

The findings of this study (table 1) showed that the weight and thickness of all the tested formulations passed the requirement for uniformity (acceptance value or L within 15\% variation) except the uniformity of thickness of formulation C (FC). The film formation of formulation A (FA, $10.57 \pm 0.03 \mathrm{mg}, 0.24 \pm 0.01 \mathrm{~mm}$ ) and formulation D (FD, $10.74 \pm 0.01 \mathrm{mg}, 0.25 \pm 0.02 \mathrm{~mm})$ were significantly $(p<0.05)$ lighter and thinner than those of formulation B (FB, $12.35 \pm 0.09 \mathrm{mg}$, $0.39 \pm 0.02 \mathrm{~mm}), \mathrm{FC}(12.03 \pm 0.09 \mathrm{mg}, 0.37 \pm 0.07 \mathrm{~mm})$ and formulation $\mathrm{E}(\mathrm{FE}, 15.73 \pm 0.07 \mathrm{mg}, 0.45 \pm 0.03 \mathrm{~mm}$ ) (table 1 ). The findings of this study showed that film thickness and weight were significantly affected by the incorporation of HPMC and PEG400 in the formulations. Films which contained HPMC (FE) were thicker and weighed more than those prepared using a single polymer (Eudragit L100) due to the higher molecular weight of HPMC compared to the methacrylate copolymer. Previous studies also reported that an increase in the concentration of plasticiser (FB) affected film thickness and weight [26]. The uniformity of film thickness and weight are of utmost importance as they are directly related to (1) uniformity and accuracy of drug content, (2) bio adhesion of formed film and (3) reproducibility of the employed formulations.

Table 1: Details on the composition and physical, mechanical properties of the formulations that passed all five criteria

\begin{tabular}{|c|c|c|c|c|c|c|c|c|c|c|c|c|}
\hline & \multicolumn{3}{|c|}{ Composition \% (w/w) } & \multicolumn{9}{|c|}{ Physical-mechanical properties } \\
\hline & $\begin{array}{l}\text { Eudragit } \\
\text { L } 100\end{array}$ & $\begin{array}{l}\text { HP } \\
\text { MC }\end{array}$ & $\begin{array}{l}\text { PEG } \\
400\end{array}$ & $\begin{array}{l}\text { Weight } \\
\text { (mg) }\end{array}$ & $\begin{array}{l}\text { Thicknes } \\
\text { s (mm) }\end{array}$ & pH & $\begin{array}{l}\text { Moisture } \\
\text { uptake } \\
(\%, w / w)\end{array}$ & $\begin{array}{l}\text { Moisture } \\
\text { content } \\
(\%, w / w)\end{array}$ & $\begin{array}{l}\text { WVP } \\
\left(\mathrm{g} / \mathrm{cm}^{2} .24 \mathrm{~h}\right)\end{array}$ & $\begin{array}{l}\text { Tensile } \\
\text { Strength } \\
\left(\mathrm{N} / \mathrm{m}^{2}\right) \\
\end{array}$ & $\begin{array}{l}\text { Percent } \\
\text { Elongation at } \\
\text { Break (\%) } \\
\end{array}$ & $\begin{array}{l}\text { Film } \\
\text { flexibility }\end{array}$ \\
\hline FA & 10 & - & 3 & $10.57 \mathrm{a} \pm .03$ & $.24^{\mathrm{a} \pm .01}$ & 5.4 & $10.90^{\mathrm{a}}$ & $39.98^{\mathrm{a}}$ & $.0014^{\mathrm{a} \pm .001}$ & $4.78^{a} \pm 0.14$ & $\begin{array}{l}33.61^{b} \pm 2.22 \\
9\end{array}$ & $\begin{array}{l}\text { Soft and } \\
\text { tough }\end{array}$ \\
\hline FB & 5 & 5 & 5 & $12.35^{\mathrm{b} \pm .09}$ & $.39^{b} \pm .02$ & 5.1 & $14.33^{a}$ & $51.41^{\mathrm{b}}$ & $.0010^{\mathrm{a} \pm .001}$ & $18.33^{c} \pm 3.10$ & $5.49^{\mathrm{a}} \pm 1.394$ & $\begin{array}{l}\text { Hard and } \\
\text { brittle }\end{array}$ \\
\hline $\mathrm{FC}$ & 5 & 5 & 3 & $12.03^{\mathrm{b}} \pm .09$ & $.37^{b} \pm .07$ & 5.3 & $13.08^{\mathrm{a}}$ & $47.01^{\mathrm{b}}$ & $.0014^{\mathrm{a} \pm .002}$ & $23.30^{c} \pm 5.93$ & $3.81^{\mathrm{a} \pm 0.806}$ & $\begin{array}{l}\text { Hard and } \\
\text { brittle }\end{array}$ \\
\hline FD & 10 & - & 5 & $10.74 \mathrm{a} \pm .01$ & $.25^{\mathrm{a} \pm .02}$ & 5.3 & $12.57^{\mathrm{a}}$ & $38.83^{\mathrm{a}}$ & $.0013^{\mathrm{a} \pm .002}$ & $4.60^{\mathrm{a}} \pm 0.44$ & $\begin{array}{l}43.11^{\mathrm{c}} \pm 3.19 \\
9\end{array}$ & $\begin{array}{l}\text { Soft and } \\
\text { tough }\end{array}$ \\
\hline $\mathrm{FE}$ & 10 & 5 & 3 & $15.73^{\mathrm{c}} \pm .07$ & $.45^{c} \pm .03$ & 5.7 & $15.07^{a}$ & $47.50^{\mathrm{b}}$ & $.0014^{\mathrm{a} \pm .001}$ & $10.7^{\mathrm{b}} \pm 3.30$ & $5.76^{\mathrm{a}} \pm 1.740$ & $\begin{array}{l}\text { Soft and } \\
\text { weak }\end{array}$ \\
\hline
\end{tabular}

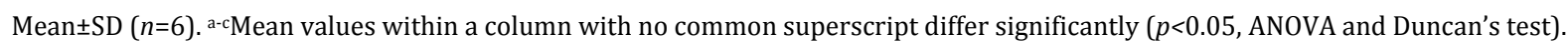

The $\mathrm{pH}$ of the film-forming solution is important to ensure that the film that is formed does not cause damage to skin or membrane leading to patient discomfort. Chemical properties of the active ingredient and its excipients determine whether the formulation is acidic or basic. In this study, the $\mathrm{pH}$ of all formulations $(\mathrm{pH}$ 5.1-5.7, table 1) was in the normal $\mathrm{pH}$ range of human skin (pH 4-6) indicating that the formed films would be a non-irritant to skin upon application [27].

The findings revealed that the dried film formulations which contained PEG400 and HPMC had significantly higher $(p<0.05)$ water content (FB, FC, and FE, 47.5\%-51.4\%) than those without HPMC (FA and FD, 38.8\%-40\%) due to hydrophilic properties since water molecules would be attracted to enter the formed films. No significant differences in moisture uptake of the formed films (10.9$15.07 \%$ ) were observed. With regard to water vapour permeability (WVP), all five films showed low water permeation with WVP less than $0.0014 \pm 0.002 \mathrm{~g} / \mathrm{cm}^{2} .24 \mathrm{~h}$ indicating a blockage in transepidermal water loss to the external environment causing saturation in the skin layer due to the hydrophobic properties of the Eudragit L100. This may lead to keratinocyte swelling and softening of skin tissue and thus accelerating drug permeability across the SC [19]. A film that has a high water absorption capacity and swelling capacity would be expected to show (1) better bio adhesion and (2) ease the release of drug principally by diffusion and/or erosion mechanism [28].

The mechanical properties of the formed film are important to ensure that the film has sufficient flexibility and elasticity. A deficiency in mechanical properties would result in cracks and fissures in the film when the patient moves. Sakellariou and Rowe classified polymeric films based on two parameters, tensile strength and elongation at break [29]. The ideal film for a topical or transdermal delivery system is one that is both soft and tough [30]. A low value for tensile strength (soft) indicates that the film is flexible enough to follow the movements of the skin, while a high percentage of elongation at break (tough) may prevent abrasion of the film. These factors would ensure patients feel more comfortable whilst using topical film-forming solutions as there would be little interference with their daily activities. In the present study (table 1), films from FA and FD showed significant $(p<0.05)$ preferred mechanical properties of the low tensile strength $\left(4.78 \mathrm{~N} / \mathrm{m}^{2}\right.$ and $4.60 \mathrm{~N} / \mathrm{m}^{2}$, respectively) and high elongation at break $(33.61 \%$ and $43.11 \%$, respectively). The tensile strength of FE was about double at $10.77 \pm 3.3 \mathrm{~N} / \mathrm{m}^{2}$, while those of films FB and FC were about five times the tensile strengths of films FA and FD at $18.33 \pm 3.10$ and $23.30 \pm 5.93 \mathrm{~N} / \mathrm{m}^{2}$, respectively. Films FA and FD were devoid of HPMC. Incorporation of HPMC into the formulations (FB, FC and FE) caused a significant $(p<0.05)$ increase in the tensile strength and lowered the percentage of elongation at break (table 1), allowing the films formed by these formulations to be hard and tough [31]. Increase of PEG400 concentrations in the formulation (FA versus FD) showed a significantly $(p<0.05)$ lower percentage of elongation at break (table 1). PEG400 is a hydrophilic polymer acting as a plasticizer that ensures the flexibility of the formed film. It has multiple hydroxyl groups and is capable of reducing the viscosity of the film-forming solution and inducing film flexibility and extendibility by reducing the glass transition temperature of the polymer [14]. Its incorporation with Eudragit L100, an anionic hydrophobic polymer, is advantageous due to the formation of hydrogen bonds with the latter [32]. This leads to a reduction in intermolecular interactions and the creation of enlarged spaces between the polymeric chains leading to an enhanced free volume which would reduce the firmness of the film and facilitate the mobility of the polymer chains [14].

\section{Drug content analysis}

Drug content uniformity remains a major challenge in formulating dosage forms. Uniformity of drug distribution is crucial in scaled-up 
product manufacturing and its validation. The drug content of each formulation (97.21-101.12\%) showed that the data obtained (table 2) were acceptable according to US Pharmacopoeia specifications (USP34).

Table 2: Summary of drug content, in vitro drug release, ex vivo skin permeation, flux, permeability coefficient and drug deposition in SC of terbinafine $\mathrm{HCl}$ in tested formulations

\begin{tabular}{|c|c|c|c|c|c|c|}
\hline & $\begin{array}{l}\text { Drug content } \\
(\%)\end{array}$ & $\begin{array}{l}\text { Cummulative } \\
\text { drug release } \\
(\%)\end{array}$ & $\begin{array}{l}\text { Cummulative amount } \\
\text { permeated }\left(\mu \mathrm{g} / \mathrm{cm}^{2}\right)\end{array}$ & $\begin{array}{l}\text { Flux, Jss } \\
\left(\mu \mathrm{g} / \mathrm{cm}^{2} \cdot h\right)\end{array}$ & $\begin{array}{l}\text { Permeability } \\
\text { coefficient, Kp } \\
(\mathrm{cm} / \mathrm{h})\end{array}$ & $\begin{array}{l}\text { Amount of terbinafine } \mathrm{HCl} \\
\text { retained in } S C\left(\mu \mathrm{g} / \mathrm{cm}^{2}\right)\end{array}$ \\
\hline FA & $98.74 \pm 3.565$ & $47.43^{c}$ & $1510.51^{\mathrm{e}} \pm 47.58$ & 1.1577 & $5.789 \mathrm{E}^{-4}$ & $6.86 \pm 0.47$ \\
\hline FB & $99.35 \pm 4.278$ & $30.57^{b}$ & $973.57^{c} \pm 63.22$ & 0.9823 & $4.912 \mathrm{E}^{-4}$ & $6.35 \pm 0.98$ \\
\hline FC & $100.08 \pm 5.102$ & $33.71^{b}$ & $1073.57^{d} \pm 75.55$ & 0.9836 & $4.918 \mathrm{E}^{-4}$ & $6.18 \pm 1.05$ \\
\hline FD & $97.21 \pm 2.114$ & $35.71^{b}$ & $1137.26^{d} \pm 69.23$ & 1.0628 & $4.814 \mathrm{E}^{-4}$ & $5.38 \pm 0.79$ \\
\hline $\mathrm{FE}$ & $101.12 \pm 5.211$ & $7.76^{\mathrm{a}}$ & $247.13^{\mathrm{a}} \pm 27.33$ & 0.2299 & $1.150 \mathrm{E}^{-4}$ & $6.15 \pm 1.28$ \\
\hline Terbex® & $103.34 \pm 6.273$ & $14.94^{\mathrm{a}}$ & $475.8^{\mathrm{b}} \pm 5.60$ & 0.444 & $2.220 \mathrm{E}^{-4}$ & $6.51 \pm 0.58$ \\
\hline
\end{tabular}

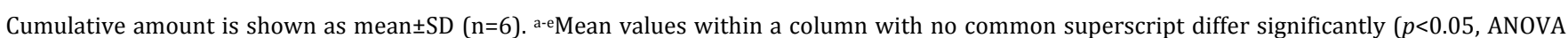
and Duncan's test).

\section{Drug release kinetics}

Terbinafine $\mathrm{HCl}$ that is present in a formulation has to be released from the polymer matrix network prior to crossing the skin barrier, the mechanism of which is driven by (1) drug dissolution, (2) drug diffusion and (3) swelling or erosion of the polymer [33]. The release kinetics of film-forming solutions were evaluated by employing data related to the kinetics of release that were fitted to several kinetic models. The results showed that most of the formulations were best fitted to the Higuichi Kinetic Model (table 3) and the coefficient of determination $\left(\mathrm{R}^{2}\right)$ ranged from 0.9527 to 0.9997 , indicating the terbinafine $\mathrm{HCl}$ release from the optimised formulations is based on Fick's law diffusion process [34]. The present tested formulations also followed the Korsmeyer-Peppas equation $\left(0.918<\mathrm{R}^{2}\right.$ value $\left.<0.995\right)$ with exponent $\mathrm{n}$ in the range of $0.38<\mathrm{n}<0.86$ (table 3 ), which represents the anomalous release mechanism $[14,15]$ in which the release is controlled both by drug diffusion, chain relaxation and erosion mechanisms [35]. This is attributed to the swelling of the matrix polymer chain and causes structural disentanglement and relaxation, which leads to diffusion of the terbinafine $\mathrm{HCl}$ through the swollen matrix [14]. All findings suggest that the drug release followed a diffusion-controlled mechanism by the formation of film through solvent evaporation leading to skin hydration and supersaturation of drug, which caused an initial rapid dissolution phase followed by a second slower release phase caused by swelling of the polymer and diffusion of drug through the swollen matrix.

Table 3: Release kinetics of the terbinafine $\mathrm{HCl}$ film-forming solutions

\begin{tabular}{|c|c|c|c|c|c|c|}
\hline \multirow[t]{2}{*}{ Formulation code } & \multirow{2}{*}{$\begin{array}{l}\text { Zero-order } \\
\text { (r value) }\end{array}$} & \multirow{2}{*}{$\begin{array}{l}\text { First-order } \\
\text { (r value) }\end{array}$} & \multirow[t]{2}{*}{ Higuchi (r value) } & \multicolumn{2}{|c|}{ Korsmeyyer-peppas } & \multirow[t]{2}{*}{ Best fit model } \\
\hline & & & & (r value) & (n value) & \\
\hline FA & 0.7849 & 0.8626 & 0.9554 & 0.9288 & 0.4631 & Higuichi \\
\hline FB & 0.9793 & 0.8987 & 0.9814 & 0.9945 & 0.8635 & Korsmeyyer \\
\hline FC & 0.9902 & 0.8921 & 0.9527 & 0.9697 & 0.6829 & Korsmeyyer \\
\hline FD & 0.8863 & 0.9032 & 0.9536 & 0.9180 & 0.3758 & Higuichi \\
\hline FE & 0.9560 & 0.9607 & 0.9959 & 0.9913 & 0.6863 & Higuichi \\
\hline Terbex $®$ & 0.9858 & 0.9903 & 0.9997 & 0.9907 & 0.7089 & Higuichi \\
\hline
\end{tabular}

\section{Drug permeation and retention across SC}

The most challenging task in cutaneous drug delivery is to overcome the strong permeation barrier of the SC, which limits drug transport. Drug penetration across the SC into viable epidermis at effective concentrations is the main goal in determining the efficiency of a topical antifungal medication. FA showed significantly $(p<0.05)$ the highest cumulative drug release and permeation across the SC at 24 $\mathrm{h}\left(47.43 \%\right.$ and $1510.51 \mu \mathrm{g} / \mathrm{cm}^{2}$, respectively) when compared to the rest of the formulations (table 2) and three-fold higher than the proprietary drug, Terbex® (14.9\% and $475.8 \mu \mathrm{g} / \mathrm{cm}^{2}$, respectively). Eudragit L100 exhibits ionic interactions and hydrogen bonding with PEG400; this is of importance in stabilising the amorphous state of drugs to prevent crystallization. Drugs in an amorphous state are thermodynamically metastable relative to the crystalline state, which leads to an enhanced drug release and permeation profile [36]. Increasing Eudragit L100 concentration from 10\% (FA) to $15 \%$ (FE) decreased the cumulative amount of drug permeation across the SC after $24 \mathrm{~h}\left(247.13 \pm 27.33 \mu \mathrm{g} / \mathrm{cm}^{2}\right)$ due to concentration-dependent matrix formation that may retard drug release from the film-forming solution. The combination polymer Eudragit L100 and HPMC in formulations (FB and FC), resulted in a significant $(p<0.05)$ decrease in skin permeation $(973.57 \pm 63.22$ $\mu \mathrm{g} / \mathrm{cm}^{2}$ and $1073.57 \pm 75.55 \mu \mathrm{g} / \mathrm{cm}^{2}$, respectively) of the drug across the SC. Previously, the use of a methacrylate copolymer alone in a formulation resulted in a significantly higher drug permeation across the SC than when it was incorporated with HPMC [37].
A low volatility of solvent upon application to the skin causes drug recrystallization [38]. In the present study, $70 \%(\mathrm{v} / \mathrm{v})$ ethanol was used, and it evaporated rapidly ( $1 \mathrm{~min}$ ) as compared to the previous study done by Reid et al. where solvent evaporation took $30 \mathrm{~min}$ leading to re-crystallization [38]. Anwar et al. and Ahad et al. reported that the use of ethanol in formulations significantly enhanced the flux of drugs across the SC compared with other solvents [25, 39]. The supersaturation of the drug prior to application, or known as transiently supersaturated preparation, is also associated with high thermodynamic activity. This would enhance cutaneous drug delivery as there will be a strong thermodynamic drive for the drug to leave the formulation leading to an increase in flux. FA was superior $\left(\mathrm{K}_{p}\right.$ of $\left.5.789 \mathrm{E}^{-4} \mathrm{~cm} / \mathrm{h}\right)$ than the other formulations (FB-FE, $\left.1.15 \mathrm{E}^{-4}-4.92 \mathrm{E}^{-4} \mathrm{~cm} / \mathrm{h}\right)$ or Terbex $囚\left(\mathrm{~K}_{p}\right.$ of $2.220 \mathrm{E}^{-4} \mathrm{~cm} / \mathrm{h}$ ). Improvement in permeability was seen in all formulations except in $\mathrm{FE}\left(1.15 \mathrm{E}^{-4} \mathrm{~cm} / \mathrm{h}\right)$ when compared to Terbex $®$. Ethanol also acts as a penetration enhancer by disrupting the intercellular lipid packing and causes diffusivity of drug across the SC [19]. The combination of ethanol and PEG400 increased the solubility of terbinafine in the formulation and caused a higher permeability coefficient [25].

The highest amount of terbinafine $\mathrm{HCl}$ deposited after $24 \mathrm{~h}$ was found in the SC of FA $\left(6.86 \mu \mathrm{g} / \mathrm{cm}^{2}\right)$ followed by Terbex® $(6.51$ $\left.\mu \mathrm{g} / \mathrm{cm}^{2}\right), \mathrm{FB}\left(6.35 \mu \mathrm{g} / \mathrm{cm}^{2}\right), \mathrm{FC}\left(6.18 \mu \mathrm{g} / \mathrm{cm}^{2}\right), \mathrm{FE}\left(6.15 \mu \mathrm{g} / \mathrm{cm}^{2}\right)$, and FD $\left(5.38 \mu \mathrm{g} / \mathrm{cm}^{2}\right)$. However, the differences were not significant. Since ethanol alters the solvency and barrier properties of the SC, it 
would be expected to be partially responsible for the deposition of terbinafine $\mathrm{HCl}[38]$.

Rapid permeation and drug depletion of tested formulations compared to Terbex ${ }^{\circledR}$ could be due to the dynamic interactions of alcohol as a chemical enhancer (in the first 1 minute of application), supersaturation of drugs and excipients (due to the evaporation of the diluents), and hydration of skin layer. Ethanol may act as a penetration enhancer whilst causing supersaturation of drugs which is the driving force for diffusion of terbinafine $\mathrm{HCl}$ across the SC. The formation of thin-film was observed after $1 \mathrm{~min}$ of application. The film may prevent water loss from the skin layer and hence cause skin hydration. This is supported by the low water vapor permeability study, which indicated a blockage of trans-epidermal water loss (less than 0.0014 $\mathrm{g} / \mathrm{cm}^{2} .24 \mathrm{~h}$ ) to the external environment causing saturation of the skin layer. Saturation of water in the skin may lead to swelling and softening of skin tissue and a marked increase in its permeability. In combination, these effects produced by the film-forming solution led to synergy in terbinafine $\mathrm{HCl}$ permeation across the $\mathrm{SC}$.
The 95\% confidence interval calculated from linear regression $\left(\mathrm{R}^{2}\right.$ values) of the kinetic profile along with the physical-mechanical properties and drug permeation study indicates strong evidence that FA was superior to the other formulations (table 1and3). Thus, FA was further examined for in vivo efficacy study.

\section{Morphological evaluation of in vivo antifungal potency}

All experimental rats were successfully infected with $1 \times 10^{6}$ $6 \times 10^{6} \mathrm{cfu} /$ unit of $T$. rubrum after $3 \mathrm{~d}$ of inoculation as skin lesions were observed. On Day 4 of treatment (fig. 2), both FA and Terbex® elicited a significant $(p<0.05)$ reduction in the size of crust formation, redness, scales, and papules of $2.25 \pm 0.11 \mathrm{~cm}^{2}$ and $2.88 \pm 0.13 \mathrm{~cm}^{2}$, respectively, compared to the negative control, untreated $\left(4 \pm 0.08 \mathrm{~cm}^{2}\right)$ or placebo $\left(4 \pm 0.09 \mathrm{~cm}^{2}\right)$ groups and this trend continued until complete healing on Day 7 of treatment. The placebo group was not significantly different from the baseline, indicating that the vehicle was without effect.

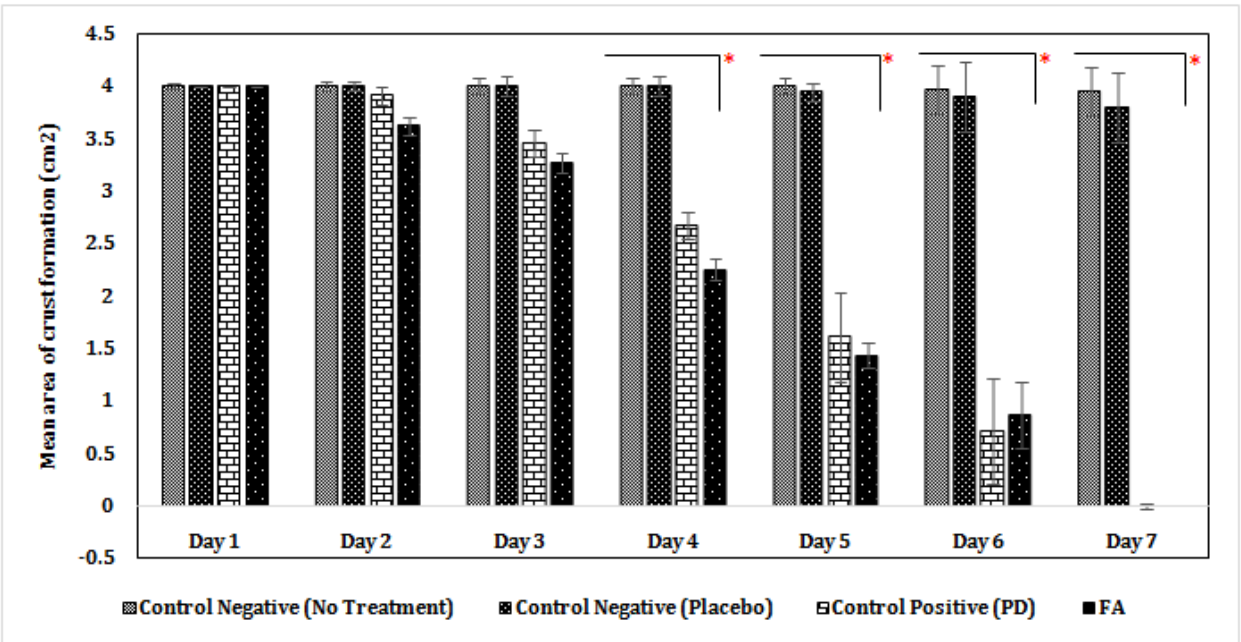

Fig. 2: Mean area of crust formation, skin lesion and papules $\left(\mathrm{cm}^{2} \pm\right.$ SD), Note: ' $*$ ' Significant difference in mean areas of crust when compared to the negative control

\section{Mycological evaluation}

The mycological study (table 4) showed a significant difference $(p<0.05)$ between treatment groups and negative control groups (placebo-treated and untreated groups). The results showed that the treatment groups (FA and Terbex ${ }^{\circledR}$ ) eradicated the dermatophyte infection almost completely (number of fungus-positive skin were 3 and 6, respectively). The average intensity of infection score of the FA $(0.5 \pm 0.84)$ was not significantly different from that of the proprietary drug, Terbex® $(1.0 \pm 0.89)$. This showed that terbinafine $\mathrm{HCl}$ in FA and Terbex® were fungicidal, which is preferred in anti-dermatophytosis compared to a fungistatic effect. Fungicidal drugs help prevent the recurrence of dermatophyte infections, while fungistatic drugs only render the infective organism unable to grow or divide.

Table 4: Therapeutic efficacy of different terbinafine formulations in the SD rats' model of dermatophytosis

\begin{tabular}{lll}
\hline & Number of fungus-positive skin* $(\mathbf{n}=\mathbf{6 0})$ & Average intensity of infection score \\
\hline Negative control (Untreated) & $56^{\mathrm{a}}$ & $9.33 \pm 0.82^{\mathrm{a}}$ \\
Negative control (Placebo) & $53^{\mathrm{a}}$ & $8.83 \pm 1.17^{\mathrm{a}}$ \\
PD & $6^{\mathrm{b}}$ & $1.00 \pm 0.89^{\mathrm{b}}$ \\
FA & $3^{\mathrm{b}}$ & $0.50 \pm 0.84^{\mathrm{b}}$ \\
\hline
\end{tabular}

*Viable growth/total number of specimens, $\mathrm{n}=60$ per group. a-bValues within a column with no common superscript differ significantly $(p<0.05$, ANOVA and Duncan's test)

\section{CONCLUSION}

The $1 \%(\mathrm{w} / \mathrm{w})$ terbinafine $\mathrm{HCl}$ film-forming solution showed advantages i.e., ease of use, convenience, and formed a thin, transparent, non-sticky film which dried in less than 1 minute. The film had high flexibility; thus it would be supple on the skin and would not be easily removed by abrasion or contact with clothing and other surfaces. All these properties would improve the compliance of patients to topical antifungal treatment. Terbinafine in both FA and Terbex® penetrated the SC and was deposited in the viable epidermis to provide a continuous drug supply over a prolonged period of time. The new formulation, FA showed a significantly higher drug flux than Terbex®. In addition, the amount of terbinafine $\mathrm{HCl}$ which permeated across the SC was higher following the application of the developed formulation when compared with the control.

Furthermore, FA had high drug content uniformity, which complied with US Pharmacopoeia specifications making it a suitable candidate for further research prior to commercialization. 


\section{ACKNOWLEDGEMENT}

Research reported in this publication was supported by grant fund 600-UiTMSEL (PI.5/4) (014/2020) and 600-RMC/GPK 5/3 (245/2020) from Universiti Teknologi MARA (UiTM).

\section{AUTHORS CONTRIBUTIONS}

All the authors have contributed equally.

\section{CONFLICT OF INTERESTS}

Declared none

\section{REFERENCES}

1. Nussipov Y, Markabayeva A, Gianfaldoni S, Tchernev G, Wollina U, Lotti J, Roccia MG, Fioranelli M, Lotti T. Clinical and epidemiological features of dermatophyte infections in Almaty, Kazakhstan. Open Access Maced J Med Sci. 2017;5(4):409-13. doi: 10.3889/oamjms.2017.124, PMID 28785320.

2. Ramamuthie G, Verma RK, Appalasamy J, Barua A. Awareness of risk factors for skin infections and its impact on quality of life among adults in a Malaysian city: A cross-sectional study. Trop J Pharm Res. 2015;14(10):1319-26. doi: 10.4314/tjpr.v14i10.25.

3. Jain N, Sharma M. Screening of thymus vulgaris essential oil against fungi causing dermatophytosis in human beings. Int J Pharm Pharm Sci. 2017;9(10):236. doi: 10.22159/ijpps.2017v9i10.20054.

4. Karimkhani C, Dellavalle RP, Coffeng LE, Flohr C, Hay RJ, Langan SM, Nsoesie EO, Ferrari AJ, Erskine HE, Silverberg JI, Vos T, Naghavi M. Global skin disease morbidity and mortality: an update from the global burden of disease Study 2013. JAMA Dermatol. 2017;153(5):406-12. doi: 10.1001/ jamadermatol.2016.5538, PMID 28249066.

5. Moubasher AH, Abdel-Sater MA, Soliman Z. Incidence and biodiversity of yeasts, dermatophytes and non-dermatophytes in superficial skin infections in Assiut, Egypt. J Mycol Med. 2017;27(2):166-79. doi: 10.1016/j.mycmed.2017.01.005, PMID 28188051.

6. Na YG, Huh HW, Kim MK, Byeon JJ, Han MG, Lee HK, Cho CW. Development and evaluation of a film-forming system hybridized with econazole-loaded nanostructured lipid carriers for enhanced antifungal activity against dermatophytes. Acta Biomater. 2020;101:507-18. doi: 10.1016/j.actbio.2019.10.024, PMID 31629894.

7. Rapalli VK, Waghule T, Hans N, Mahmood A, Gorantla S, Dubey SK, Singhvi G. Insights of lyotropic liquid crystals in topical drug delivery for targeting various skin disorders. J Mol Liq. 2020;315. doi: 10.1016/j.molliq.2020.113771, PMID 113771.

8. Zhu J, Tang X, Jia Y, Ho CT, Huang Q. Applications and delivery mechanisms of hyaluronic acid used for topical/transdermal delivery- a review. Int J Pharm. 2020;578:119127. doi: 10.1016/j.ijpharm.2020.119127.

9. Khurana A, Sardana K, Chowdhary A. Antifungal resistance in dermatophytes: recent trends and therapeutic implications. Fungal Genet Biol. 2019;132:103255. doi: 10.1016/j.fgb.2019.103255.

10. Rather IA, Kim BC, Bajpai VK, Park YH. Self-medication and antibiotic resistance: crisis, current challenges, and prevention. Saudi J Biol Sci. 2017;24(4):808-12. doi: 10.1016/j.sjbs.2017.01.004, PMID 28490950.

11. Hay R. Therapy of skin, hair and nail fungal infections. J Fungi (Basel). 2018;4(3). doi: 10.3390/jof4030099, PMID 30127244.

12. Ayukekbong JA, Ntemgwa $M$, Atabe AN. The threat of antimicrobial resistance in developing countries: causes and control strategies. Antimicrob Resist Infect Control. 2017;6:47. doi: 10.1186/s13756-017-0208-x, PMID 28515903.

13. Jimenez Garcia L, Celis Aguilar E, Diaz Pavon G, Estrada MV. Efficacy of topical clotrimazole vs. topical tolnaftate in the treatment of otomycosis. A randomized controlled clinical trial. Braz J Otorhinolaryngol. 2020;86:300-7.

14. Monica LL, Jordi G, Francisco FC. In situ bioadhesive filmforming system for topical delivery of mometasone furoate: characterization and biopharmaceutical properties. J Drug Delivery Sci Technol. 2020;59. doi: 10.1016/ j.jddst.2020.101852, PMID 101852.
15. Yang F, Yu X, Shao W, Guo P, Cao S, Wang M, Wang Y, Wu C, Xu Y. Co-delivery of terbinafine hydrochloride and urea with an in situ film-forming systems for nail targeting treatment. Int J Pharm. 2020;585:119497. doi: 10.1016/j.ijpharm.2020.119497.

16. Mori NM, Patel P, Sheth NR, Rathod LV, Ashara KC. Fabrication and characterization of film-forming voriconazole transdermal spray for the treatment of fungal infection. Bull Fac Pharm Cairo Univ. 2017;55(1):41-51. doi: 10.1016/j.bfopcu.2017.01.001.

17. Li X, Zhang R, Liang R, Liu W, Wang C, Su Z, Sun F, Li Y. Preparation and characterization of sustained-release Rotigotine film-forming gel. Int J Pharm. 2014;460(1-2):273-9. doi: 10.1016/j.ijpharm.2013.11.015, PMID 24269287.

18. Liu X, Fu L, Dai W, Liu W, Zhao J, Wu Y, Teng L, Sun F, Li Y. Design of transparent film-forming hydrogels of tolterodine and their effects on stratum corneum. Int J Pharm. 2014;471(1-2):322-31. doi: 10.1016/j.ijpharm.2014.05.051, PMID 24882035.

19. Thapa RK, Choi JY, Han SD, Lee GH, Yong CS, Jun JH, Kim JO. Therapeutic effects of a novel DA5505 formulation on a guinea pig model of tinea pedis. Dermatol Sin. 2017;35(2):59-65. doi: 10.1016/j.dsi.2016.11.001.

20. Zurdo Schroeder I, Franke P, Schaefer UF, Lehr CM. Development and characterization of film-forming polymeric solutions for skin drug delivery. Eur J Pharm Biopharm. 2007;65(1):111-21. doi: 10.1016/j.ejpb.2006.07.015, PMID 16950609.

21. U. S. In: Pharmacopoeial Convention. Vol. 905. United States Pharmacopeia (USP). US Pharmacopeia; 2011. p. 4-6.

22. Ng SF, Tan SL. Development and in vitro assessment of alginate bilayer films containing the olive compound hydroxytyrosol as an alternative for topical chemotherapy. Int J Pharm 2015;495(2):798-806. doi: 10.1016/j.jpharm.2015.09.057, PMID 26434999.

23. Zhang W, Wang XC, Wang JJ, Zhang LL. Drugs adsorption and release behavior of collagen/bacterial cellulose porous microspheres. Int J Biol Macromol. 2019;140:196-205. doi: 10.1016/j.ijbiomac.2019.08.139, PMID 31430489.

24. Jaiswal P, Das S, Das M. Boosting the skin delivery of curcumin through stearic acid-ethyl cellulose blend hybrid nanocarriersbased approach for mitigating psoriasis. Int J Appl Pharm. 2021;13:150-64. doi: 10.22159/ijap.2021v13i3.40668

25. Anwar E, Ramadon D, Ardi GD. Novel transethosome containing green tea (Camellia sinensis l. Kuntze) leaf extract for enhanced skin delivery of epigallocatechin gallate: formulation and in vitro penetration test. Int J App Pharm. 2018;10(1):299. doi: 10.22159/ijap.2018.v10s1.66.

26. Kathe K, Kathpalia H. Film forming systems for topical and transdermal drug delivery. Asian J Pharm Sci. 2017;12(6):48797. doi: 10.1016/j.ajps.2017.07.004, PMID 32104362.

27. Gokhale JP, Mahajan HS, Surana SJ. Quercetin loaded nanoemulsion-based gel for rheumatoid arthritis: in vivo and in vitro studies. Biomed Pharmacother. 2019;112:108622. doi: 10.1016/j.biopha.2019.108622.

28. Li J, Mooney DJ. Designing hydrogels for controlled drug delivery. Nat Rev Mater. 2016/10/18;1(12). doi: 10.1038/natrevmats.2016.71, PMID 29657852.

29. Sakellariou P. Interactions in cellulose derivative films for oral drug delivery. Prog Polym Sci. 1995;20(5):889-942. doi: 10.1016/0079-6700(95)00008-4.

30. Mishra DK, Pandey V, Maheshwari R, Ghode P, Tekade RK. Chapter 15. Cutaneous and transdermal drug delivery: techniques and delivery systems. In: Tekade RKBT-BF of DD. Academic Press; 2019. p. 595-650.

31. Tighsazzadeh M, Mitchell JC, Boateng JS. Development and evaluation of performance characteristics of timolol-loaded composite ocular films as potential delivery platforms for the treatment of glaucoma. Int J Pharm. 2019;566:111-25. doi: 10.1016/j.ijpharm.2019.05.059, PMID 31129346.

32. Khatri P, Desai D, Shelke N, Minko T. Role of plasticizer in membrane coated extended-release oral drug delivery system. J Drug Delivery Sci Technol. 2018;44:231-43. doi: 10.1016/j.jddst.2017.12.020.

33. Ustundag Okur N, Filippousi M, Okur ME, Ayla S, Caglar ES, Yoltas A, Siafaka PI. A novel approach for skin infections: controlled release topical mats of poly(lactic acid)/poly(ethylene succinate) 
blends containing voriconazole. J Drug Delivery Sci Technol. 2018;46:74-86. doi: 10.1016/j.jddst.2018.05.005.

34. Sagiroglu AA, Ozsoy Y, Ozer O. Design, optimization and characterization of novel topical formulations containing triamcinolone acetonide. J Drug Delivery Sci Technol. 2020;58. doi: 10.1016/j.jddst.2020.101594, PMID 101594.

35. Elmotasem H, Awad GEA. A stepwise optimization strategy to formulate in situ gelling formulations comprising fluconazolehydroxypropyl-beta-cyclodextrin complex loaded niosomal vesicles and Eudragit nanoparticles for enhanced antifungal activity and prolonged ocular delivery. Asian J Pharm Sci. 2020;15(5):617-36. doi: 10.1016/j.ajps.2019.09.003, PMID 33193864 .

36. Banerjee S, Chattopadhyay P, Ghosh A, Datta P, Veer V. Aspect of adhesives in transdermal drug delivery systems. Int J Adhes Adhes. 2014;50:70-84. doi: 10.1016/j.ijadhadh.2014.01.001.
37. Morales JO, Huang S, Williams RO, McConville JT. Films loaded with insulin-coated nanoparticles (ICNP) as potential platforms for peptide buccal delivery. Colloids Surfaces B Biointerfaces. 2014;122:38-45. doi: 10.1016/j.colsurfb.2014.05.025, PMID 25016543.

38. Reid ML, Benaouda F, Khengar R, Jones SA, Brown MB. Topical corticosteroid delivery into human skin using hydrofluoroalkane metered-dose aerosol sprays. Int J Pharm. 2013;452(1-2):157-65. doi: 10.1016/j.ijpharm.2013.04.083, PMID 23684656.

39. Ahad A, Al-Jenoobi FI, Al-Mohizea AM, Akhtar N, Raish M, Aqil M. Systemic delivery of $\beta$-blockers via transdermal route for hypertension. Saudi Pharm J. 2015;23(6):587-602. doi: 10.1016/j.jsps.2013.12.019, PMID 26702253. 